\title{
Chronic low-intensity noise exposure affects the hearing thresholds of juvenile snapper
}

\author{
Paul E. Caiger*, John C. Montgomery, Craig A. Radford \\ Leigh Marine Laboratory, University of Auckland, PO Box 349, Warkworth 0941, New Zealand
}

\begin{abstract}
A growing body of evidence suggests that larval fish use sound as an orientation cue to remotely locate suitable settlement habitats. Several theoretical models have used hearing thresholds to estimate the distance at which fish larvae can detect reefs. However, researchers have often measured hearing thresholds from fish raised in aquaculture environments, or held them in closed-system tanks once caught, where equipment can significantly increase the noise levels in the tanks. The possibility arises that exposure to such noise negatively affects the hearing ability of the fish held there, such that distances predicted from these studies may be underestimated. The objective of this study was to compare the hearing ability of wild versus aquacultured snapper Pagrus auratus using auditory evoked potentials. Juvenile snapper from aquaculture tanks had significantly higher hearing thresholds at 100, 200 and $400 \mathrm{~Hz}$ than wild snapper. A controlled noise-exposure experiment, where snapper were exposed for 2 wk to low-intensity noise at $120 \mathrm{~dB}$ re $1 \mu \mathrm{Pa}$, confirmed these results. When plotted using an extended reef-based model, the distance at which aquaculture-raised snapper are predicted to detect a particular reef was half of that found for their wild counterparts. Clearly, the acoustic history of experimental subjects is an important consideration when using hearing thresholds to make ecological estimations, such as the distance at which larvae could detect reefs.
\end{abstract}

KEY WORDS: Fish hearing - Orientation cue - Threshold shift - Aquaculture noise - Auditory evoked potential $\cdot$ AEP $\cdot$ Pagrus auratus

Resale or republication not permitted without written consent of the publisher

\section{INTRODUCTION}

The majority of reef fishes have a bipartite life cycle, including a pelagic phase where they undergo feeding, ontogenetic development and growth in the open ocean (Leis 2006), yet at the end of this stage they must locate a reef upon which to settle. Although fish larvae were once thought to be passive particles (Roberts 1997), it is now clear that they are active in their dispersal and settlement, through well-developed orientation and swimming abilities (for a review, see Leis 2006). Furthermore, fish form their sensory organs early in their larval development, usually within the first few days of life (Leis \& McCormick 2002), and there are several potential cues that larvae may be able to use to provide directed swimming. These include, but are not lim- ited to, chemical cues, polarised light, hydrodynamic cues, and magnetic and electrical fields (Montgomery et al. 2006). However, it is sound that has been highlighted as having the strongest potential as a long distance orientation cue (Simpson et al. 2004, Montgomery et al. 2006), due in part to underwater sound being fast and far reaching, suffering little attenuation (Rodgers \& Cox 1988), and having the ability to convey habitat information in a directional manner (Radford et al. 2010).

There is some conjecture as to the magnitude of orientation to settlement habitat sound cues. Some studies propose that sound is useful at remotely detecting reefs from a significant distance (Leis et al. 2003, Simpson et al. 2004, Leis \& Lockett 2005, Radford et al. 2011; Wright et al. 2011), whilst others suggest that hearing abilities are not sensitive enough to 
be ecologically meaningful, and larvae could only detect sound at distances of $\sim 1 \mathrm{~km}$ or less (Myrberg \& Fuiman 2002, Egner \& Mann 2005, Mann et al. 2007). Clearly, the effective range depends on source intensity and transmission, but also on the measured hearing sensitivity of larvae (Radford et al. 2011). A large proportion of hearing thresholds have been conducted on fish sourced from aquaculture facilities, or housed in closed-system aquaria. The acoustic conditions fish are exposed to in these environments are not necessarily equivalent to those they would encounter in the wild. Only a select few facilities have consciously maintained animals in quieter flowthrough systems (e.g. Wright et al. 2005), or tested fish immediately upon capture (e.g. Wright et al. 2008).

Aquaculture noise has been shown to have detrimental effects on growth and reproduction, as well as induce stress in aquaculture animals (Wysocki et al. 2007, Davidson et al. 2009), and 2 studies have shown that this noise could adversely affect hearing (Wysocki et al. 2007, Gutscher et al. 2011). Fish in hatchery and culture settings are exposed to relatively loud ambient noise levels, particularly in recirculating systems, due to the use of machinery, water circulation and air supply. In closed environments, fish are unable to escape from areas with loud noise, and thus are exposed to chronic elevated sound levels that are well within their hearing ranges (Wysocki et al. 2007), often 20 to $50 \mathrm{~dB}$ re $1 \mu \mathrm{Pa}$ higher than in their natural habitats (Bart et al. 2001). Sound levels and frequencies recorded in commercial settings range from 125 to $135 \mathrm{~dB}$ re $1 \mu \mathrm{Pa}$ at $25-1000 \mathrm{~Hz}$, and from 100 to $115 \mathrm{~dB}$ re $1 \mu \mathrm{Pa}$ at $1-2 \mathrm{kHz}$ (Bart et al. 2001), but have been recorded as high as 153 (Bart et al. 2001) and $160 \mathrm{~dB}$ re $1 \mu \mathrm{Pa}$ (Clark et al. 1996). Even sound levels present in leisure aquaria with external filters can reach $119 \mathrm{~dB}$ re $1 \mu \mathrm{Pa}$ (Gutscher et al. 2011).

A number of field- and laboratory-based experiments have examined the effects of high-intensity sounds on fish hearing. The first such study was by Enger (1981), who showed that exposure to highintensity pure tones resulted in damage to the sensory hair cells of the Atlantic cod Gadhus morhua. Additionally, the oscar Astronotus ocellatus was exposed to continuous hour-long tones at $180 \mathrm{~dB}$ re $1 \mu \mathrm{Pa}$ and damage to hair cells was found in response to a $300 \mathrm{~Hz}$ stimulus; although other frequencies and shorter durations caused no damage to the fish's ears (Hastings et al. 1996). McCauley et al. (2003) exposed caged snapper Pagrus auratus to seismic air guns (203.6 dB re $1 \mu \mathrm{Pa} @ 1 \mathrm{~m}$ ) in situ and observed severe damage to the sensory hair cells, with no sign of recovery or repair up to $58 \mathrm{~d}$ post-exposure. Hearing in goldfish Carassius auratus was even affected by the filter noise of an aquarium, with the largest shifts in threshold (between 15 and $19 \mathrm{~dB}$ re $1 \mu \mathrm{Pa}$ ) at 100 and $300 \mathrm{~Hz}$ (Gutscher et al. 2011).

Contrary to these findings, other species have shown little to no change in hearing after sound exposure. For example, exposure to a seismic device (mean peak sound pressure level [SPL], with all sound intensities referred to in this document as root mean square [RMS]: $207.3 \mathrm{~dB}$ re $1 \mu \mathrm{Pa}$ ) had no effect on the thresholds or ears of broad whitefish Coregonus nasus (Popper et al. 2005). Nor did low-frequency $(200-500 \mathrm{~Hz}$ ) sonar at $193 \mathrm{~dB}$ re $1 \mu \mathrm{Pa}$ affect the rainbow trout Onchorhyncus mykiss (Popper et al. 2007). There was no hearing loss in several other fish species exposed to a similar sonar exposure (Scholik \& Yan 2002, Halvorsen et al. 2006). Noise exposure can have an effect on fish hearing, so noise history may be an important thing to consider when assessing thresholds from which to make ecologically relevant predictions of acoustic range.

The present study aims to determine the effect of aquaculture noise on the hearing ability of juvenile snapper Pagrus auratus in order to gain a greater understanding of the significance of underwater sound as an orientation cue. Firstly, the electrophysiology technique of auditory evoked potentials (AEPs) were used to make direct comparison between wild and aquaculture-raised snapper. Secondly, auditory abilities of juvenile snapper were investigated using AEPs when the fish were exposed to low-intensity noise under experimental conditions.

\section{MATERIALS AND METHODS}

\section{Fish acquisition and maintenance}

Juvenile snapper were caught from the wild using beach seine nets dragged over sub-tidal seagrass (Zostera sp.) habitats in Kaipara Harbour, New Zealand (NZ) $\left(36^{\circ} 44^{\prime} \mathrm{S}, 174^{\circ} 39^{\prime} \mathrm{E}\right)$, while aquaculture-raised snapper were supplied by Plant and Food Research, Nelson, NZ. All fish were held in flowthrough holding tanks at the Leigh Marine Laboratory, NZ, supplied with ambient $\left(\sim 18\right.$ to $\left.20^{\circ} \mathrm{C}\right)$ seawater. Fish were fed once daily with a mixture of finely chopped pilchard Sardinia neopilchardus and squid Nototodarus sp. All experiments and animal care were undertaken in accordance with the University of Auckland Animal Ethics grant R782. 


\section{Auditory evoked potentials}

Hearing thresholds were determined for snapper using auditory evoked potentials (AEPs). AEPs provide an instantaneous measure of hearing ability by measuring an electrical response to sound stimuli in the eighth cranial nerve and brainstem auditory nuclei. AEP methodology used in our study has been adapted from Higgs et al. (2003) and Wright et al. (2005, 2008, 2010).

For AEP testing, snapper were anaesthetised with a solution of 2-phenoxy-ethanol (0.004 M) before the experiment to reduce movement in the fish holder (see below) and then completely submerged underwater in a PVC tank $(0.5 \mathrm{~mm}$ thick, $1.2 \mathrm{~m}$ long, $0.25 \mathrm{~m}$ diameter). Initial experiments showed that the anaesthetic had no effect on fish hearing. The anaesthetised snapper were positioned laterally upon a piece of plasticine on a Perspex slide attached at a perpendicular angle to a plastic pipette (custom fish holder). A piece of stocking was firmly positioned around the snapper's body as a restraint, whilst allowing respiration to occur normally. No muscle relaxants were needed for these experiments. The fish was placed $\sim 8 \mathrm{~cm}$ below the water surface, and $75 \mathrm{~cm}$ from an underwater speaker (University Sound UW-30) placed at the opposite end of the tank.

Auditory stimuli and AEP waveform recordings were produced with a Tucker-Davis Technologies workstation running SigGen (Version 4.4) and BioSig (Version 4.4) software. Stimuli consisted of $10 \mathrm{~ms}$ tone bursts with a $2 \mathrm{~ms}$ rise-fall time gated through a Hanning window, with 7 different frequencies presented from 100 to $2000 \mathrm{~Hz}$, covering the expected range of fish hearing (Popper \& Fay 1999). Acoustic stimuli were calibrated daily with a High Tech HTI96-Min series hydrophone (sensitivity -163.7 dB V/1 $\mu \mathrm{Pa})$ positioned in the tank in the same place as the fish's head. An oscilloscope (Hewlett Packard) was then used to measure SPL at each frequency, which was then attenuated through SigGen to output the desired decibel levels.

Three 27 gauge subdermal stainless steel electrodes (Rochester Electromedical) coated in nail varnish for insulation (except for the tip) were used to collect the AEP signals. The recording electrode was placed dorsally, just posterior to the operculum, the reference electrode was placed dorsally in the nasal region, and a ground electrode was placed in the fish holder's plasticine. Fish were periodically checked during experiments, mostly by means of operculum and mouth movement.
The presentation order of the frequencies was conducted randomly, to a maximum source level of $145 \mathrm{~dB}$ re $1 \mu \mathrm{Pa}$ (speaker limitations), and frequencies were increased in $5 \mathrm{~dB}$ increments until a stereotypical AEP was seen, and then continued for at least another $10 \mathrm{~dB}$ to examine supra-threshold responses. To cancel stimulus artefacts, averages of 200 pulsed tones from each phase (90 and $270^{\circ}$ phases) were taken for each SPL at each frequency. The auditory threshold was visually defined as the lowest level at which a clear response could be detected (Fig. 1). Visual detection has been shown to produce results comparable to statistical approaches (Kenyon et al. 1998, Mann et al. 2001). As a control, dead fish were tested in the apparatus; at no time did they produce a result that resembled a response waveform (Fig. 1).
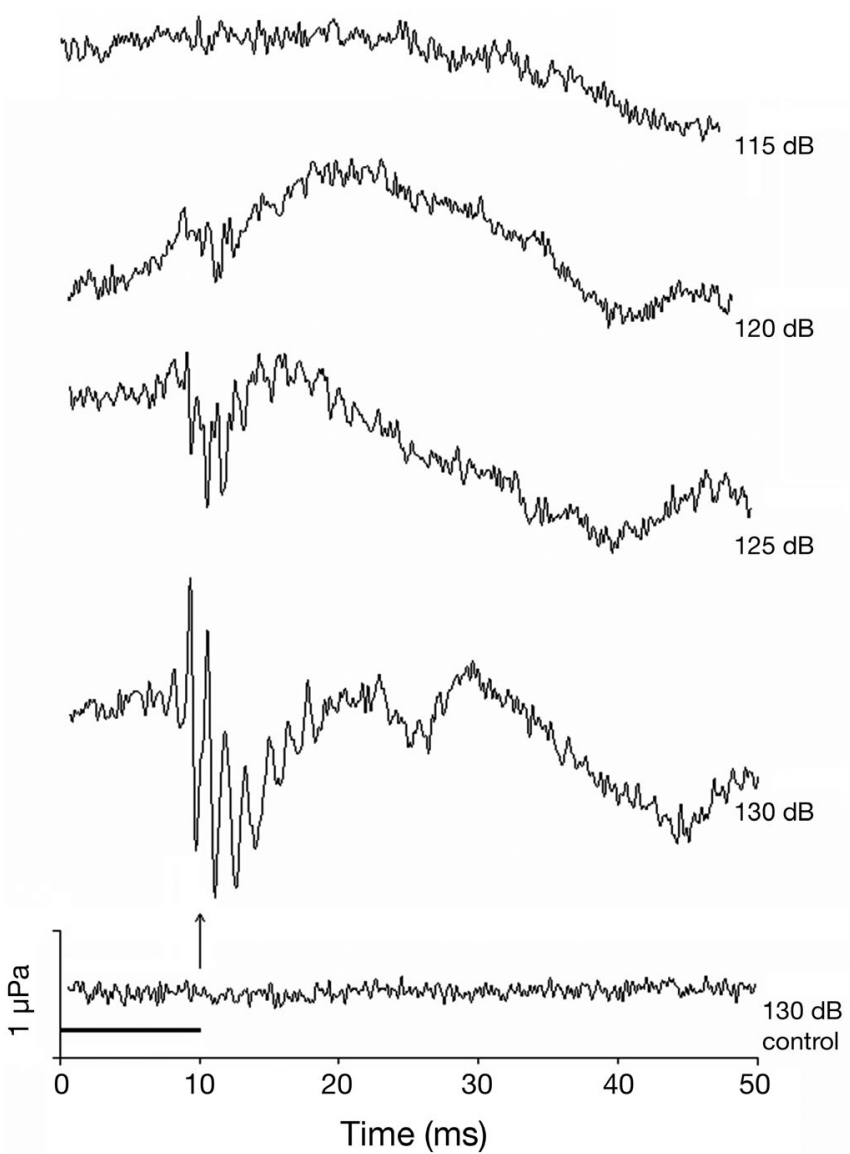

Fig. 1. Example of auditory evoked potential (AEP) waveforms for a juvenile snapper, Pagrus auratus in response to sound stimuli of $400 \mathrm{~Hz}$ tone bursts. Black bar under the traces: stimulus duration (10 ms). Arrow: start position of the response. The auditory threshold, or the lowest sound pressure level (SPL) to show a response in the example waveform, occurred in this particular fish at $120 \mathrm{~dB}$ re $1 \mu \mathrm{Pa}$ at $400 \mathrm{~Hz}$. Control AEPs were performed with dead fish 


\section{Noise-exposure experiment}

Wild-caught juvenile snapper were exposed to 2 different treatments. Immediately after catch, the juveniles were housed in 2 identical, rectangular flow-through PVC tanks. One tank had 2 ceramic airstones submerged, running full flow (sound level $120 \mathrm{~dB}$ re $1 \mu \mathrm{Pa}$ i.e. noisy), whilst the other did not (sound level $107 \mathrm{~dB}$ re $1 \mu \mathrm{Pa}$, i.e. silent). After $2 \mathrm{wk}$, AEP tests were performed. Due to the $40 \mathrm{~dB}$ loss of sound energy at the air-water interface (Parvulescu 1964), very little sound energy should have transferred between the 2 tanks, which were housed in the same room. The sound levels in the PVC tanks were recorded using an HTI-96-Min Series hydrophone (sensitivity $-163.7 \mathrm{~dB} \mathrm{~V} / 1 \mu \mathrm{Pa}$ ) and an Edirol R-09HR digital recorder. The tanks from which the aquaculture-raised snapper were supplied were also recorded, and are referred to in the text hereafter as Nelson aquaculture tanks.

\section{Data analysis}

Appropriate tests on ranks were performed where data were not normally distributed and/or of unequal variance. One-way ANOVA on ranks (KruskalWallis tests) were used to test for significant differences in hearing thresholds between the 3 groups of snapper (aquaculture, silent and noise-exposed) and between median fork lengths of the 3 groups. Where significant differences were found, Dunn's post-hoc tests were conducted to make pairwise comparisons. For all tests, the significance level was set at $\alpha=0.05$.

Digital recordings were analysed and plotted as power spectra and octave bands (with centre frequencies of 125, 250, 500, 1000, 2000, 4000, 8000 and $16000 \mathrm{~Hz}$ ) using MATLAB 2009a software, with codes specifically written for this work. Although spectrum plots are more commonly used, they may not truly represent the way marine animals perceive sound, because they do not incorporate the critical bands of the auditory system (Ghazali 2012). Therefore, presenting the sound power in the relevant critical band ( $N$ th octave band level) is probably more meaningful in the context of sound perception, because it approximates the auditory filter of marine teleosts (Au \& Hastings 2009). The acoustic power spectra and octave band plots for each tank were generated using fast Fourier transform analyses of 10 s samples, selected randomly from 30 s recordings. Sound recordings were analysed after being filtered through a digital band-pass filter between
50 and $24000 \mathrm{~Hz}$. To calculate the differences of sound in the 2 tank treatments, the sound intensity $\left(\mathrm{SPL}_{\mathrm{rms}}\right)$ for the overall bandwidth and for frequency bandwidths with notable peaks, was calculated using MATLAB 2009a.

\section{RESULTS}

\section{Wild versus aquacultured snapper}

Juvenile wild-caught and aquacultured snapper had bandwidths of auditory sensitivity ranging from 100 to $2000 \mathrm{~Hz}$ (Fig. 2). Depending on the frequency presented, the auditory thresholds ranged from $101 \mathrm{~dB}$ re $1 \mu \mathrm{Pa}$ to at least $145 \mathrm{~dB}$ re $1 \mu \mathrm{Pa}$ for the wild-caught snapper, and from $111 \mathrm{~dB}$ re $1 \mu \mathrm{Pa}$ to at least $145 \mathrm{~dB}$ re $1 \mu \mathrm{Pa}$ for the aquacultured snapper. Both groups of fish were most sensitive at the lowest frequency $(100 \mathrm{~Hz})$, with their hearing ability slowly decreasing as the frequencies increased (Fig. 2). Aquacultured snapper had significantly less sensitive hearing than wild-caught snapper $\left(H_{20}=235.11\right.$, $\mathrm{p}<0.001$ ), with significant increases in mean auditory thresholds observed at 100, 200 and $400 \mathrm{~Hz}$.

\section{Noise-exposure experiment}

Tank sound analysis

The loudest region of both tank recordings was in the bandwidth between 50 and $1000 \mathrm{~Hz}$ (Fig. 3a). There was an increase in the overall intensity of the

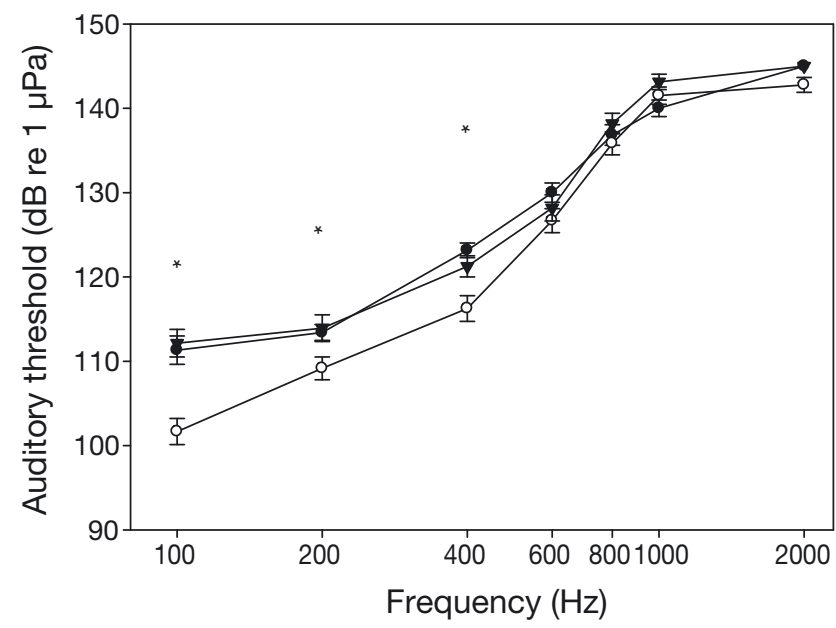

Fig. 2. Auditory thresholds (mean \pm SEM) for aquacultureraised $(\bullet, \mathrm{n}=19)$, wild-caught noise-exposed $(\boldsymbol{\nabla}, \mathrm{n}=14)$ and wild-caught silently kept $(\mathrm{O}, \mathrm{n}=12)$ juvenile snapper Pagrus auratus. ${ }^{*}$ : significant difference $(\mathrm{p}<0.05)$ 


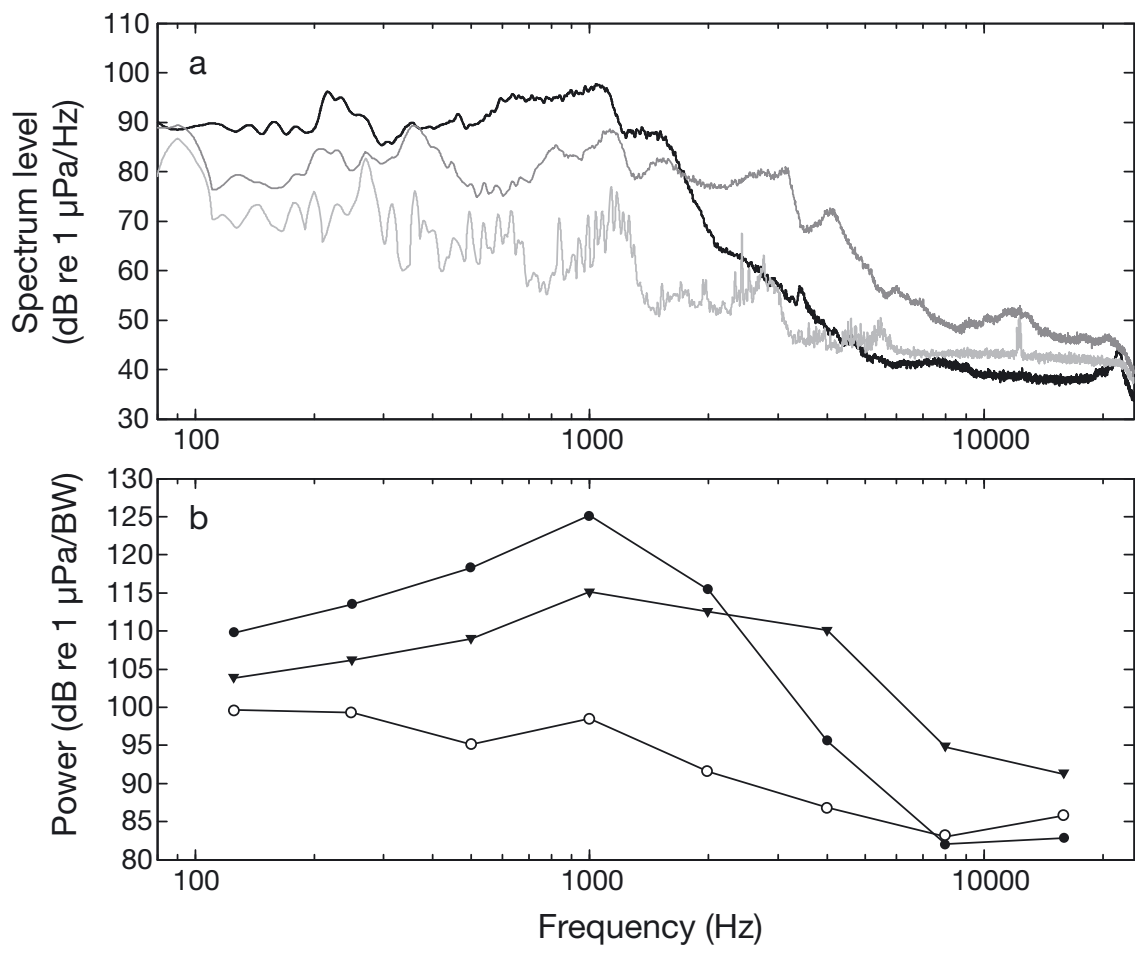

Fig. 3. Comparisons between underwater sound in the experimental tanks (noisy and silent) and the Nelson aquaculture tanks. (a) Power spectrum level plot comparing the noise-exposed (dark grey line), the silent (light grey line) and the Nelson (black line) tank. (b) Octave band level plot comparing the noise-exposed

$(\boldsymbol{\nabla})$, the silent $(\mathrm{O})$ and the Nelson aquaculture $(\bullet)$ tank. BW $=$ band width thresholds significantly increased between noise-exposed and silent treatments $\left(H_{20}=235.11, \mathrm{p}<0.001\right)$, with significant increases observed at 100, 200 and $400 \mathrm{~Hz}$. However, hearing thresholds between noiseexposed and silent fish were similar for frequencies above $400 \mathrm{~Hz}$ (Fig. 2). There were no significant differences in auditory thresholds between the aquacultured and noise-exposed groups of snapper when comparing the respective frequencies.

\section{DISCUSSION}

A growing body of evidence suggests that larval fish use sound to locate suitable settlement habitats. Egner \& Mann (2005), Mann et al. (2007) and Wright et al. (2011) have used theoretical models with the hearing thresholds of fish to estimate the distance at which larvae can detect reefs. We unambiguously showed that snapper exposed to aquaculture-like noise do tank levels by over an order of magnitude between the silent tank and the noise-exposed tank (107 to $120 \mathrm{~dB}$ re $1 \mu \mathrm{Pa}$, respectively). Octave bands analysis also showed a marked rise of sound intensity in the octave bands 3, 4, 5 and 6 between the silent and noise-exposed tanks (Fig. 3b). The biggest rise was observed in octave band 6 , with a sound intensity of $110 \mathrm{~dB}$ re $1 \mu \mathrm{Pa}$ for the noise-exposed tank compared with $86 \mathrm{~dB}$ re $1 \mu \mathrm{Pa}$ for the silent tank. Overall, the underwater sound intensity was 14 to $24 \mathrm{~dB}$ re $1 \mu \mathrm{Pa}$ higher in the noise-exposed tank compared with the silent tank in those 4 octave bands. The overall SPL of the aquaculture facility tank was $128 \mathrm{~dB}$ re $1 \mu \mathrm{Pa}$ (Fig. 3).

\section{Hearing thresholds}

There were no significant differences between the median snapper fork lengths of any groups of snapper tested in this study $\left(H_{2}=0.774, \mathrm{p}=0.679\right)$, with fork lengths (mean $\pm \mathrm{SD}$ ) of $53.4 \pm 3.8,55.3 \pm 6.2$ and $53.4 \pm 4.9 \mathrm{~mm}$ for aquacultured, noise-exposed and silent snapper groups, respectively. Mean auditory not possess as good a hearing ability compared with those that were not exposed to this noise. Because many previous studies have obtained thresholds from fish that have been exposed to chronic noise (i.e. closed-system tanks), calculations of the distance at which larvae can detect reefs could be underestimated.

With the use of an extended reef-based model (Radford et al. 2011), combined with the measured sounds of temperate reefs (145 dB re $1 \mu \mathrm{Pa}$ ) (Radford et al. 2008), the hearing thresholds in the present study were used to calculate an approximate distance of reef detection for snapper (Fig. 4). This model incorporated an extended reef zone (as opposed to a point sound source) where cylindrical spreading does not occur at distances less than the length of the reef. Also, fittingly, the sound measurements are from northeastern New Zealand, where snapper are native. If we assume that the hearing of newly settled juvenile snapper hearing is equivalent to that of late-stage larvae, and using the frequency with the lowest threshold $(100 \mathrm{~Hz})$, then snapper would be capable of detecting this particular reef from a distance of $\sim 36 \mathrm{~km}$ away, a significant dis- 


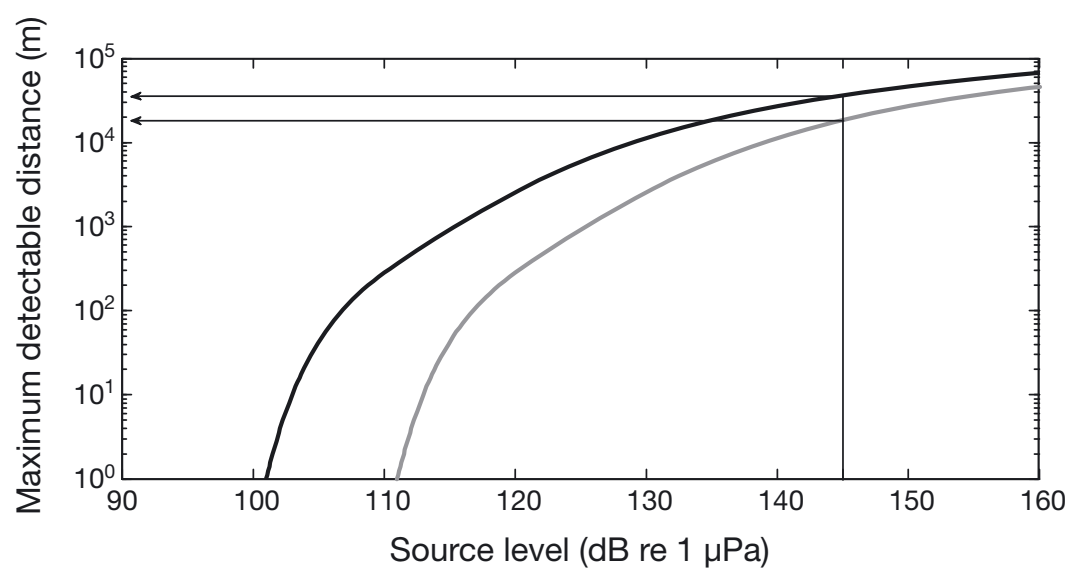

Fig. 4. Estimated maximum distance of sound detection as a function of source level, calculated from the extended reef model (Radford et al. 2011) for juvenile snapper Pagrus auratus. Curves are anchored on the $x$-axis by the snapper's lowest hearing thresholds (black curve for wild snapper: $101 \mathrm{~dB}$ re $1 \mu \mathrm{Pa}$ @ $100 \mathrm{~Hz}$; grey curve for aquacultured snapper: $110 \mathrm{~dB}$ re $1 \mu \mathrm{Pa} @ 100 \mathrm{~Hz}$ ). Arrows signify the intercept with the $y$-axis (the estimated detection distances for both groups of snapper), calculated from the intersect between the measured sound level from a temperate reef on the $x$-axis (145 dB re $1 \mu \mathrm{Pa}$; Radford et al. 2008) and the snapper thresholds (curves)

tance offshore. When the lowest auditory threshold for the aquacultured snapper is plotted on the same graph, it is apparent that the snapper can only detect the reef in question from a distance of $\sim 18 \mathrm{~km}$ away, half of that of the wild snapper (Fig. 4).

It must be noted, however, that snapper were most sensitive at $100 \mathrm{~Hz}$, and it is unknown what frequencies of the reef sound spectra larvae might be using to locate the reef. Previous research has shown that in fish without specialisations, the auditory fish brain is most sensitive to the natural complex sounds (either conspecific calls or environmental sounds), which are probably more important signals than simple tones (Wysocki \& Ladich 2003, Maruska \& Tricas 2009, Wright et al. 2010). In the study used to calculate the model, there was a broad peak from 500 to $2500 \mathrm{~Hz}$ centred at $\sim 1400 \mathrm{~Hz}$ (Radford et al. 2011), which is most likely due to the resonating tests of grazing sea urchins. The hearing ability of juvenile snapper is most sensitive at the lower frequencies $(<1000 \mathrm{~Hz})$; therefore, the dominant sound energy emanating from the reef does not necessarily match the frequency segments the snapper are most able to hear. Perhaps, more realistically, they are hearing a broad spectrum of frequencies, which makes it difficult to isolate the exact sound segments the larvae are sensitive to, and to calculate exact distances. Therefore, the estimates calculated above should be seen as the maximum likely distances at which a snapper larva may be able to detect the reef.
Regardless, we would suggest that fishes with thresholds matching, or better than, those in our study are likely to be able to detect underwater sounds emanating from reefs at distances significant enough to be useful in terms of directing settlement.

Significant shifts in thresholds were found between the groups of snapper at the lowest frequencies, and these could well be due to the noise generated by the motors of the filters and machinery. In aquaculture systems, the lower frequency ranges (25 to $1000 \mathrm{~Hz}$ ) are generally louder than higher frequency regions (Bart et al. 2001), and recordings of the aquaculture tank in our study confirm this. Without recording the natural environment, it is difficult to directly compare what sound characteristics and levels both groups of fish were exposed to prior to auditory testing. Of course the natural environment is not a silent world, and in some areas, particularly coastal zones, animals are subject to loud anthropogenic noises (Popper \& Hastings 2009). Direct comparison between these 2 groups of snapper must therefore be made with caution, and this ambiguity led to the noise exposure experiments in the present study.

Even under low-intensity noise exposure, the hearing thresholds of juvenile snapper were negatively affected. The sound levels in the Nelson aquaculture tanks (128 dB re $1 \mu \mathrm{Pa}$ ) were comparable to those in the noisy experimental tank $(120 \mathrm{~dB}$ re $1 \mu \mathrm{Pa})$ from our study, and also to the recordings from Bart et al.'s (2001) survey of aquaculture systems. Furthermore, analysis of the tank recordings showed that peaks in the octave band analysis for all tanks were highest in the fourth octave band, at a frequency centred at $1000 \mathrm{~Hz}$. A centre frequency of $1000 \mathrm{~Hz}$ encompasses the broad peaks observed between 700 and $2000 \mathrm{~Hz}$ that dominate underwater sound in temperate waters around northern New Zealand reefs (Radford et al. 2008). This suggests that the frequencies that the snapper were exposed to are well within their hearing range and similar to biologically relevant sounds that they might encounter in the wild, albeit at different levels. Importantly, this highlights the potential of underestimating thresholds of any species raised in a laboratory environment, especially given that many hearing tests are performed on fishes that are exposed to some degree of chronic sound exposure. 
Efforts to minimise sound exposure pre-testing, such as testing immediately post-catch (in wild fishes) or using flow-through systems, would mitigate this problem somewhat.

Fish species with different hearing abilities are affected differently by exposure to a given noise level. The snapper in the present study showed hearing losses of up to $10 \mathrm{~dB}$. Snapper do not possess a mechanical connection between the swim bladder and the ears, and can be said to have mid to poor hearing ability. However, even fishes without specialised linkages may still be sensitive to acoustic pressure, through what is known as an indirect stimulus, where the swim bladder vibrations radiate to the inner ear indirectly (Coombs \& Popper 1979, Montgomery et al. 2006). Extensive hearing loss of up to $30 \mathrm{~dB}$ has been described in species with more sensitive hearing abilities (Scholik \& Yan 2001, Amoser \& Ladich 2003, Smith et al. 2004); therefore, there is the possibility that hearing loss could be larger in fishes with specialisations if they were exposed to the same experimental conditions.

Whilst shifts were observed in auditory thresholds, it is not known whether these shifts were temporary or permanent. Several studies have reported that hearing loss in fishes can be temporary, whereby their hearing recovers post-noise exposure. These temporary threshold shifts were first documented in goldfish (Popper \& Clarke 1976), and have been confirmed more recently in several other species of fish (Scholik \& Yan 2001, Amoser \& Ladich 2003, Smith et al. 2004, 2006). This recovery in hearing is most likely due to the proliferation of new hair cells (Popper \& Hoxter 1984, Lombarte \& Popper 1994) or the regeneration of damaged ones (Lombarte et al. 1993, Smith et al. 2006, Schuck \& Smith 2009), although there may be other mechanisms involved for temporary shifts in hearing. As we do not know whether snapper hearing would recover post-noise exposure, recovery experiments are needed to elucidate this.

In conclusion, it is apparent from our threshold data study that even under low-intensity noise exposure, such as is found in aquaculture settings, the hearing ability of juvenile snapper was impaired. Sound levels in husbandry tanks are reported to be much higher than those investigated here. Moreover, as many studies obtain hearing thresholds from fish raised in aquaculture facilities or closed-system holding tanks, the thresholds of such individuals may be underestimated. Based on data from our study and an extended reef-based model, it is proposed that the hearing ability of snapper is significant enough to play a role in detecting reefs from a distance.
Acknowledgements. We thank Alistair Jerrett and colleagues from Plant and Food, Nelson, NZ, for the supply of juvenile snapper. We are also grateful to the anonymous reviewers, and staff at the Leigh Marine Laboratory.

\section{LITERATURE CITED}

Amoser S, Ladich F (2003) Diversity in noise-induced temporary hearing loss in otophysine fishes. J Acoust Soc Am 113:2170-2179

$\mathrm{Au}$ WWL, Hastings MC (2009) Auditory systems of marine animals. In: $\mathrm{Au}$ WWL, Hastings MC (eds) Principles of marine bioacoustics. Springer, New York, NY, p 227-282

> Bart AN, Clark J, Young J, Zohar Y (2001) Underwater ambient noise measurements in aquaculture systems: a survey. Aquacult Eng 25:99-110

Clark J, Young J, Bart AN, Zohar Y (1996) Underwater ambient noise measurements. In: 30th Proceedings of the Acoustical Society of America. St Louis, MO, p 13

Coombs S, Popper AN (1979) Hearing differences among Hawaiian squirrelfish (family Holocentridae) related to differences in the peripheral auditory system. J Comp Physiol 132:203-207

> Davidson J, Bebak J, Mazik P (2009) The effects of aquaculture production noise on the growth, condition factor, feed conversion, and survival of rainbow trout, Oncorhynchus mykiss. Aquaculture 288:337-343

Egner SA, Mann DA (2005) Auditory sensitivity of sergeant major damselfish (Abudefduf saxatilis) from postsettlement juvenile to adult. Mar Ecol Prog Ser 285: 213-222

Enger PS (1981) Frequency discrimination in teleosts - central or peripheral? In: Tavolga WN, Popper AN, Fay RR (eds) Hearing and sound communication in fishes. Springer, New York, NY, p 243-255

Ghazali SM (2012) Fish vocalisation: understanding its biological role from temporal and spatial characteristics. PhD thesis, University of Auckland

Gutscher M, Wysocki LE, Ladich F (2011) Effects of aquarium and pond noise on hearing sensitivity in an otophysine fish. Bioacoustics 20:117-136

Halvorsen MB, Wysocki LE, Popper AN (2006) Effects of high-intensity sonar on fish. J Acoust Soc Am 119:3283

> Hastings MC, Popper AN, Finneran JJ, Lanford PJ (1996) Effects of low-frequency underwater sound on hair cells of the inner ear and lateral line of the teleost fish Astronotus ocellatus. J Acoust Soc Am 99:1759-1766

Higgs DM, Rollo AK, Souza MJ, Popper AN (2003) Development of form and function in peripheral auditory structures of the zebrafish (Danio rerio). J Acoust Soc Am 113: 1145-1154

Kenyon TN, Ladich F, Yan HY (1998) A comparative study of hearing ability in fishes: the auditory brainstem response approach. J Comp Physiol A 182:307-318

Leis JM (2006) Are larvae of demersal fishes plankton or nekton? Adv Mar Biol 51:57-141

Leis JM, Lockett MM (2005) Localization of reef sounds by settlement-stage larvae of coral-reef fishes (Pomacentridae). Bull Mar Sci 76:715-724

Leis JM, McCormick MI (2002) The biology, behavior, and ecology of the pelagic, larval stage of coral reef fishes. In: Sale PF (ed) Coral reef fishes: dynamics and diversity in a complex ecosystem. Academic Press, San Diego, CA, p 171-200 
Leis JM, Carson-Ewart BM, Hay AC, Cato DH (2003) Coral reef sounds enable nocturnal navigation by some reeffish larvae in some places and at some times. J Fish Biol 63:724-737

Lombarte A, Popper AN (1994) Quantitative analyses of postembryonic hair cell addition in the otolithic endorgans of the inner ear of the European hake, Merluccius merluccius (Gadiformes, Teleostei). J Comp Neurol 345:419-428

Lombarte A, Yan HY, Popper AN, Chang JS, Platt C (1993) Damage and regeneration of hair cell ciliary bundles in a fish ear following treatment with gentamicin. Hear Res 64:166-174

Mann DA, Higgs DM, Tavolga WN, Souza MJ, Popper AN (2001) Ultrasound detection by clupeiform fishes. J Acoust Soc Am 109:3048-3054

- Mann DA, Casper BM, Boyle KS, Tricas TC (2007) On the attraction of larval fishes to reef sounds. Mar Ecol Prog Ser 338:307-310

Maruska KP, Tricas TC (2009) Encoding properties of auditory neurons in the brain of a soniferous damselfish: response to simple tones and complex conspecific signals. J Comp Physiol A 195:1071-1088

> McCauley RD, Fewtrell J, Popper AN (2003) High intensity anthropogenic sound damages fish ears. J Acoust Soc Am 113:638-642

Montgomery JC, Jeffs A, Simpson SD, Meekan M, Tindle C (2006) Sound as an orientation cue for the pelagic larvae of reef fishes and decapod crustaceans. Adv Mar Biol 51: 143-196

Myrberg AA, Fuiman LA (2002). The sensory world of coral reef fishes In: Sale PF (ed) Coral reef fishes: dynamics and diversity in a complex ecosystem. Academic Press, San Diego, CA, p 123-148

Parvulescu A (1964) Problems of propagation and processing. In: Tavolga WN (ed) Marine biocoustics. Pergamon Press, Oxford, p 87-100

Popper AN, Clarke NL (1976) Auditory system of goldfish (Carassius auratus) - effects of intense acoustic stimulation. Comp Biochem Physiol A 53:11-18

Popper AN, Fay RR (1999) The auditory periphery in fishes. In: Fay RR, Popper AN (eds) Comparative hearing: fishes and amphibians. Springer-Verlag, New York, NY, p 43-100

Popper AN, Hastings MC (2009) The effects of anthropogenic sources of sound on fishes. J Fish Biol 75:455-489

Popper AN, Hoxter B (1984) Growth of a fish ear. 1. Quantitative analysis of sensory hair cell and ganglion cell proliferation. Hear Res 15:133-142

Popper AN, Smith ME, Cott PA, Hanna BW, MacGillivray AO, Austin ME, Mann DA (2005) Effects of exposure to seismic airgun use on hearing of three fish species. J Acoust Soc Am 117:3958-3971

Popper AN, Halvorsen MB, Kane E, Miller DD, Smith ME, Stein P, Wysocki LE (2007) The effects of high-intensity, low-frequency active sonar on rainbow trout. J Acoust Soc Am 122:623-635

Editorial responsibility: Nicholas Tolimieri, Seattle, Washington, USA
Radford CA, Jeffs AG, Tindle CT, Montgomery JC (2008) Temporal patterns in ambient noise of biological origin from a shallow water temperate reef. Oecologia 156: 921-929

Radford CA, Stanley JA, Tindle CT, Montgomery JC, Jeffs AG (2010) Localised coastal habitats have distinct underwater sound signatures. Mar Ecol Prog Ser 401:21-29

- Radford CA, Tindle CT, Montgomery JC, Jeffs AG (2011) Modelling a reef as an extended sound source increases the predicted range at which reef noise may be heard by fish larvae. Mar Ecol Prog Ser 438:167-174

> Roberts CM (1997) Connectivity and management of Caribbean coral reefs. Science 278:1454-1457

Rodgers PH, Cox M (1988) Underwater sound as a biological stimulus. In: Atema J, Fay RR, Popper AN, Tavolga WN (eds) Sensory biology of aquatic animals. SpringerVerlag, New York, NY, p 131-149

Scholik AR, Yan HY (2001) Effects of underwater noise on auditory sensitivity of a cyprinid fish. Hear Res 152:17-24

Scholik AR, Yan HY (2002) The effects of noise on the auditory sensitivity of the bluegill sunfish, Lepomis macrochirus. Comp Biochem Physiol A 133:43-52

Schuck JB, Smith ME (2009) Cell proliferation follows acoustically-induced hair cell bundle loss in the zebrafish saccule. Hear Res 253:67-76

Simpson SD, Meekan MG, McCauley RD, Jeffs AG (2004) Attraction of settlement-stage coral reef fishes to reef noise. Mar Ecol Prog Ser 276:263-268

Smith ME, Kane AS, Popper AN (2004) Noise-induced stress response and hearing loss in goldfish (Carassius auratus). J Exp Biol 207:427-435

Smith ME, Coffin AB, Miller DL, Popper AN (2006) Anatomical and functional recovery of the goldfish (Carassius auratus) ear following noise exposure. J Exp Biol 209: 4193-4202

> Wright KJ, Higgs DM, Belanger AJ, Leis JM (2005) Auditory and olfactory abilities of pre- and post-settlement juveniles of a coral damselfish (Pisces: Pomacentridae). Mar Biol 147:1425-1434

> Wright KJ, Higgs DM, Belanger AJ, Leis JM (2008) Auditory and olfactory abilities of larvae of the Indo-Pacific coral trout Plectropomus leopardus (Lacepede) at settlement. J Fish Biol 72:2543-2556

Wright KJ, Higgs DM, Cato DH, Leis JM (2010) Auditory sensitivity in settlement-stage larvae of coral reef fishes. Coral Reefs 29:235-243

Wright KJ, Higgs DM, Leis JM (2011) Ontogenetic and interspecific variation in hearing ability in marine fish larvae. Mar Ecol Prog Ser 424:1-13

- Wysocki LE, Ladich F (2003) The representation of conspecific sounds in the auditory brainstem of teleost fishes. J Exp Biol 206:2229-2240

> Wysocki LE, Davidson JW, Smith ME, Frankel AS and others (2007) Effects of aquaculture production noise on hearing, growth, and disease resistance of rainbow trout Oncorhynchus mykiss. Aquaculture 272:687-697

Submitted: April 26, 2012; Accepted: July 9, 2012 Proofs received from author(s): October 1, 2012 